\title{
OCCUPATIONAL VIRAL HEPATITIS IN THE SLOVAK AND THE CZECH REPUBLIC
}

\author{
Jana Buchancová1, Viera Švihrová', L'ubomír Legáth ${ }^{2}$, Oto Osina ${ }^{3}$, Pavel Urban $^{4,5}$, Zdenka Fenclová ${ }^{4,5}$, \\ Jana Zibolenová', Dana Rošková', Lukáš Murajda', Henrieta Hudečková1 \\ ${ }^{1}$ Department of Public Health, Jessenius Faculty of Medicine, Comenius University, Martin, Slovakia \\ ${ }^{2}$ Clinic of Occupational Medicine and Clinical Toxicology, P. J. Šafárik University, Košice, Slovakia \\ ${ }^{3}$ Clinic of Occupational Medicine and Toxicology, Jessenius Faculty of Medicine, Comenius University, Martin, Slovakia \\ ${ }^{4}$ Center of Occupational Health, National Institute of Public Health, Prague, Czech Republic \\ ${ }^{5}$ Department of Occupational Medicine, 1st Faculty of Medicine, Charles University, Prague, Czech Republic
}

\section{SUMMARY}

Background: The proportion of occupational infectious diseases (ID) in the total number of occupational diseases reported in the Slovak Republic (SR) and the Czech Republic (CR) was decreasing from 1973 to 2010. Our study presents a longitudinal analysis of the occurrence of occupational infectious diseases in the Slovak Republic and the Czech Republic in the period from 1973-2010 with special focus on viral hepatitis.

Methods: The sources of data were national health statistics of Czechoslovakia, the Czech Republic and the Slovak Republic. Descriptive statistical methods were used for data analysis. Incidence rate of reported diseases was calculated per 100,000 general population or per 100,000 people insured.

Results: During the studied period, a total of 2,931 and 8,318 cases of occupational viral hepatitis (VH) were reported in the Slovak Republic and the Czech Republic, respectively. The incidence culminated in the late 1970 s when hepatitis represented almost $50 \%$ of all reported occupational infectious diseases. Most cases of occupational hepatitis occurred in health and social services. Since the early 1980s, a steep decrease in the incidence of hepatitis has been observed due to the gradual implementation of mandatory vaccination against hepatitis $A$ and $B$ in risk groups.

In SR in 1973, the incidence rate of occupational infectious diseases and that of occupational viral hepatitis was 10.85/100,000 and 1.86/100,000, respectively. In 2010, these rates decreased to $0.74 / 100,000$ and $0.20 / 100,000$, respectively.

In CR, the incidence rates of occupational infectious diseases and that of occupational viral hepatitis reported in 1973 were 11.75/100,000 and $3.69 / 100,000$. In 2010, reported incidence rates were $1.71 / 100,000$ and $0.10 / 100,000$, respectively.

Conclusion: Although the incidence of occupational viral hepatitis has dramatically decreased in the Slovak and the Czech Republic as well as in other Visegrad group countries during the studied period, we emphasize the necessity of continuing epidemiological surveillance of hepatitis, especially with regard to the recent incidence increase of viral hepatitis $\mathrm{C}$.

Key words: occupational infections, occupational viral hepatitis, Czech Republic, Slovak Republic, development trends, incidence rate, vaccination

Address for correspondence: J. Buchancová, Department of Public Health, Jessenius Faculty of Medicine, Comenius University, Sklabinska 26, 03601 Martin, Slovakia. E-mail: buchancova@jfmed.uniba.sk

\section{INTRODUCTION}

Infectious diseases represent one of the categories of occupational diseases (OD) with high incidence, both in the Slovak and the Czech Republic. The following communicable diseases belong among typical OD: viral hepatitis $(\mathrm{VH})$, tuberculosis, brucellosis, anthrax, and tetanus $(1,2)$. Besides, some of the national lists of OD include SARS, avian influenza in farmers, and AIDS (1,3-7).

Our study presents a longitudinal analysis of the occurrence of occupational infectious diseases in the Slovak Republic (SR) and the Czech Republic (CR) in the period from 1973-2010, focused on viral hepatitis.

\section{MATERIAL AND METHODS}

Data were acquired from medical statistics issued from 1974-2011 by the national Institutes of Health Information and Statistics of both the Czech and the Slovak Republic and other sources (8-15). Descriptive methods of statistical analysis for evaluation of collected data were used. The incidence rate of reported occupational diseases, occupational infectious diseases, and occupational viral hepatitis per 100,000 general population, and from 1991 per 100,000 people insured, was calculated.

\section{RESULTS}

Table 1 shows both absolute numbers and the incidence rates of reported occupational diseases, occupational infectious diseases, and occupational viral hepatitis in SR and CR per 100,000 general population.

It can be seen that the absolute numbers of reported occupational diseases in SR and in CR in the analyzed period decreased. (Note: in CR, the atypical years 1990 and 1991 should be disregarded. The unusually high numbers of reported OD in the mentioned two years were the consequence of politically enforced "reclassifications".) If we compare numbers of OD cases in the 
Table 1. Absolute numbers of cases of the reported occupational diseases, occupational infectious diseases, and occupational viral hepatitis and incidence per 100,000 general population in SR and CR

\begin{tabular}{|c|c|c|c|c|c|c|c|c|c|c|c|c|}
\hline \multirow[b]{3}{*}{ Year } & \multicolumn{6}{|c|}{ SR } & \multicolumn{6}{|c|}{ CR } \\
\hline & \multicolumn{2}{|r|}{ OD } & \multicolumn{2}{|r|}{ ID } & \multicolumn{2}{|c|}{ VH } & \multicolumn{2}{|r|}{$O D$} & \multicolumn{2}{|r|}{ ID } & \multicolumn{2}{|r|}{ VH } \\
\hline & $\mathrm{N}$ & $\begin{array}{c}\text { per } \\
100,000 \\
\text { general } \\
\text { population }\end{array}$ & $\mathrm{N}$ & $\begin{array}{c}\text { per } \\
100,000 \\
\text { general } \\
\text { population }\end{array}$ & $\mathrm{N}$ & $\begin{array}{c}\text { per } \\
100,000 \\
\text { general } \\
\text { population }\end{array}$ & $\mathrm{N}$ & $\begin{array}{c}\text { per } \\
100,000 \\
\text { general } \\
\text { population }\end{array}$ & $\mathrm{N}$ & $\begin{array}{c}\text { per } \\
100,000 \\
\text { general } \\
\text { population }\end{array}$ & $\mathrm{N}$ & $\begin{array}{c}\text { per } \\
100,000 \\
\text { general } \\
\text { population }\end{array}$ \\
\hline 1973 & 1,399 & 30.29 & 501 & 10.85 & 86 & 1.86 & 3,470 & 34.98 & 1,166 & 11.75 & 366 & 3.69 \\
\hline 1974 & 1,249 & 26.78 & 445 & 9.54 & 81 & 1.74 & 3,498 & 35.00 & 1,227 & 12.28 & 394 & 3.94 \\
\hline 1975 & 1,269 & 26.92 & 623 & 13.21 & 93 & 1.97 & 3,568 & 35.46 & 1,374 & 13.65 & 430 & 4.27 \\
\hline 1976 & 1,371 & 28.78 & 645 & 13.54 & 134 & 2.81 & 4,152 & 40.99 & 1,642 & 16.21 & 556 & 5.49 \\
\hline 1977 & 1,356 & 28.16 & 384 & 7.97 & 160 & 3.32 & 4,261 & 41.82 & 876 & 8.60 & 556 & 5.46 \\
\hline 1978 & 1,347 & 27.68 & 541 & 11.12 & 164 & 3.37 & 3,951 & 38.56 & 1,349 & 13.17 & 485 & 4.73 \\
\hline 1979 & 1,225 & 24.93 & 542 & 11.03 & 180 & 3.66 & 4,059 & 39.42 & 1,391 & 13.51 & 505 & 4.90 \\
\hline 1980 & 1,367 & 27.54 & 551 & 11.10 & 205 & 4.13 & 3,552 & 34.40 & 1,263 & 12.23 & 620 & 6.00 \\
\hline 1981 & 1,437 & 28.76 & 570 & 11.41 & 208 & 4.16 & 3,840 & 37.27 & 1,106 & 10.73 & 458 & 4.45 \\
\hline 1982 & 1,299 & 25.79 & 483 & 9.59 & 148 & 2.94 & 3,806 & 36.90 & 919 & 8.91 & 408 & 3.96 \\
\hline 1983 & 1,150 & 22.66 & 416 & 8.20 & 142 & 2.80 & 2,954 & 28.62 & 883 & 8.55 & 419 & 4.06 \\
\hline 1984 & 1,188 & 23.25 & 440 & 8.61 & 162 & 3.17 & 3,403 & 32.94 & 990 & 9.58 & 450 & 4.36 \\
\hline 1985 & 1,277 & 24.82 & 479 & 9.31 & 151 & 2.94 & 3,248 & 31.42 & 884 & 8.55 & 402 & 3.89 \\
\hline 1986 & 1,196 & 23.09 & 469 & 9.06 & 129 & 2.49 & 3,532 & 34.16 & 876 & 8.47 & 385 & 3.72 \\
\hline 1987 & 1,241 & 23.83 & 487 & 9.35 & 126 & 2.42 & 3,895 & 37.64 & 836 & 8.08 & 307 & 2.97 \\
\hline 1988 & 1,128 & 21.54 & 413 & 7.89 & 70 & 1.34 & 3,729 & 36.01 & 738 & 7.13 & 268 & 2.59 \\
\hline 1989 & 1,041 & 19.78 & 372 & 7.07 & 87 & 1.65 & 3,805 & 36.72 & 665 & 6.42 & 226 & 2.18 \\
\hline 1990 & 1,194 & 22.58 & 347 & 6.56 & 70 & 1.32 & 11,673 & 112.64 & 657 & 6.34 & 130 & 1.25 \\
\hline 1991 & 1,311 & 24.69 & 266 & 5.01 & 58 & 1.09 & 8,680 & 84.20 & 486 & 4.71 & 137 & 1.33 \\
\hline 1992 & 1,076 & 20.32 & 292 & 5.51 & 66 & 1.25 & 3,393 & 32.88 & 484 & 4.69 & 116 & 1.12 \\
\hline 1993 & 939 & 17.67 & 296 & 5.57 & 57 & 1.07 & 3,051 & 29.53 & 508 & 4.92 & 115 & 1.11 \\
\hline 1994 & 772 & 14.47 & 193 & 3.62 & 39 & 0.73 & 2,698 & 26.10 & 461 & 4.46 & 68 & 0.66 \\
\hline 1995 & 601 & 11.22 & 165 & 3.08 & 45 & 0.84 & 2,875 & 27.83 & 506 & 4.90 & 80 & 0.77 \\
\hline 1996 & 726 & 13.53 & 197 & 3.67 & 41 & 0.76 & 2,543 & 24.65 & 488 & 4.73 & 79 & 0.77 \\
\hline 1997 & 697 & 12.96 & 139 & 2.58 & 30 & 0.56 & 2,376 & 23.06 & 362 & 3.51 & 74 & 0.72 \\
\hline 1998 & 740 & 13.74 & 164 & 3.04 & 42 & 0.78 & 2,111 & 20.51 & 459 & 4.46 & 15 & 0.15 \\
\hline 1999 & 673 & 12.48 & 125 & 2.32 & 21 & 0.39 & 1,886 & 18.34 & 310 & 3.01 & 50 & 0.49 \\
\hline 2000 & 660 & 12.23 & 112 & 2.07 & 29 & 0.54 & 1,751 & 17.05 & 287 & 2.79 & 39 & 0.38 \\
\hline 2001 & 577 & 10.73 & 106 & 1.97 & 23 & 0.43 & 1,677 & 16.40 & 313 & 3.06 & 28 & 0.27 \\
\hline 2002 & 609 & 11.32 & 76 & 1.41 & 11 & 0.20 & 1,600 & 15.69 & 301 & 2.95 & 24 & 0.24 \\
\hline 2003 & 551 & 10.24 & 94 & 1.75 & 14 & 0.26 & 1,558 & 15.27 & 288 & 2.82 & 24 & 0.24 \\
\hline 2004 & 613 & 11.39 & 103 & 1.91 & 10 & 0.19 & 1,388 & 13.60 & 234 & 2.29 & 25 & 0.24 \\
\hline 2005 & 413 & 7.67 & 69 & 1.28 & 8 & 0.15 & 1,400 & 13.68 & 278 & 2.72 & 22 & 0.21 \\
\hline 2006 & 504 & 9.35 & 43 & 0.80 & 3 & 0.06 & 1,216 & 11.84 & 164 & 1.60 & 12 & 0.12 \\
\hline 2007 & 575 & 10.66 & 39 & 0.72 & 0 & 0.00 & 1,291 & 12.51 & 176 & 1.70 & 7 & 0.07 \\
\hline 2008 & 429 & 7.94 & 39 & 0.72 & 8 & 0.15 & 1,403 & 13.45 & 202 & 1.94 & 12 & 0.12 \\
\hline 2009 & 483 & 8.92 & 52 & 0.96 & 19 & 0.35 & 1,313 & 12.51 & 229 & 2.18 & 16 & 0.15 \\
\hline 2010 & 425 & 7.83 & 40 & 0.74 & 11 & 0.20 & 1,292 & 12.28 & 180 & 1.71 & 10 & 0.10 \\
\hline $\begin{array}{l}\text { Total/ } \\
\text { mean }\end{array}$ & 36,108 & 18.59 & 11,318 & 5.90 & 2,931 & 1.53 & 119,898 & 30.69 & 25,558 & 6.56 & 8,318 & 2.14 \\
\hline
\end{tabular}

OD - occupational diseases

ID - occupational infectious diseases

$\mathrm{VH}$ - viral hepatitis 
last years of the interval 1973-2010, decrease in reported OD cases by $70 \%$ and $63 \%$ in SR and CR, respectively, is evident.

From 1973 to 2010, the proportion of occupational infectious diseases in the total number of occupational diseases reported in SR and CR was decreasing. In SR, the highest proportion of ID was in 1975 and 1976 when it reached almost 50\%. In 2010, it was only $9 \%$. In CR, the highest proportion was in 1976, when it reached $40 \%$. In 2010, it represented only 14\% (again, years 1990 and 1991 should be disregarded).

Table 1 shows dramatic decline in the occurrence of occupational viral hepatitis in SR and CR from 1973-2010.

The incidence of reported occupational infectious diseases, occupational viral hepatitis per 100,000 people insured is shown in Figures 1-3. From a long-term point of view, the occurrence of occupational hepatitis in Slovakia was higher than in the Czech Republic.

As shown in Figure $4(a, b)$, this positive change was in correlation mainly with the decreasing occurrence of hepatitis B, which was attributable to the implementation of obligatory vaccination against hepatitis B in occupational groups at highest risk. Occupational viral hepatitis occurred mainly in the economic sector of health care services. Cases reported from other economic sectors were only sporadic (e.g. employees in detention facilities for immigrants, cleaners, garbage collectors, teachers, etc.).

Remark: Since the categorized data on types of viral hepatitis were not available in SR until 1992 and in CR until 1993, part of the cases were not categorized, we present these as "unclassified" (Fig. 5 a, b).

As regards the structure of reported cases of occupational viral hepatitis according to type, comparable data from SR and

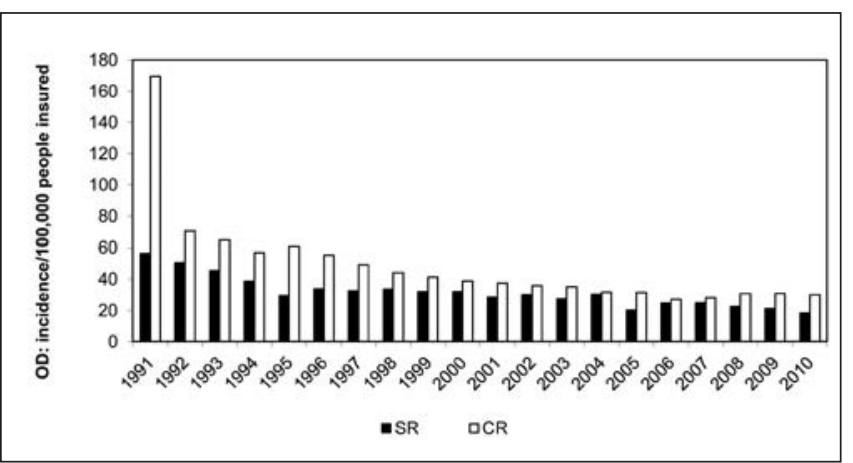

Fig. 1. Incidence of reported occupational diseases per 100,000 people insured in SR and CR from 1991-2010.

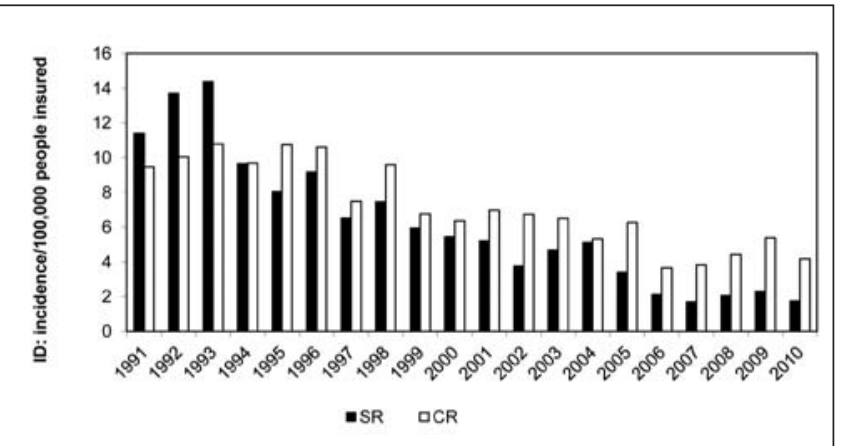

Fig. 2. Incidence of reported infectious diseases per 100,000 people insured in SR and CR from 1991-2010.

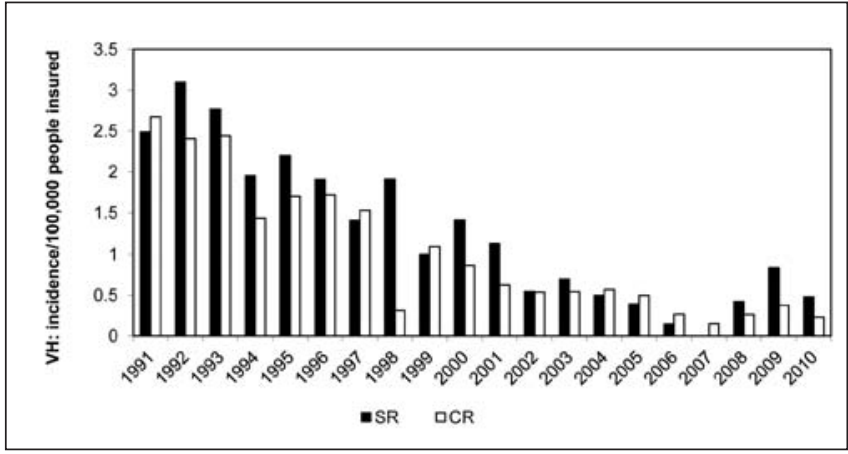

Fig. 3. Incidence of reported occupational viral hepatitis per 100,000 people insured in SR and CR from 1991-2010.

CR could be ascertained for the period 1991-2010. During the period, 593 cases of occupational viral hepatitis were reported in $\mathrm{SR}$, and 1,008 cases in CR. The structure is shown in Fig. $5 \mathrm{a}, \mathrm{b}$ with acute hepatitis B prevailing both in SR and CR during the studied period, acute hepatitis A ranked second in SR while in $\mathrm{CR}$, it was chronic form of hepatitis B.

Potential severity of hepatitis is illustrated by two case reports: Case Report No. 1

34 years aged surgeon was hospitalized at the Department of infectious diseases for hepatitis epidemica, icteric type (Bilirubin $111.15 \mu \mathrm{mol} / \mathrm{l}$, GOT $11.27 \mu \mathrm{kat} / \mathrm{l})$. There was a suspicion that the disease is of an occupational origin but infectologists did not refer the patient to the Department of Occupational Medicine (year 1962). The patient died aged 44 years. The autopsy revealed severe liver cirrhosis, esophageal and stomach varices, and stasis in $\mathrm{v}$. portae, melaena and bleeding from gastrointestinal tract. Epidemiological evaluation was performed after death. Non-occupational contacts were not found. On the contrary, occupational contacts with two patients suffering from hepatitis were identified. Because the surgeon regularly worked with pump of extracorporal blood circulation and worked also at intensive care units, it was made clear that he had been at risk of infection. Department of occupational medicine recommended that the patient's fatal disease should be acknowledged as OD, and that financial compensation should be provided to his widow and two small children. Case Report No. 2

A stomatologist working in an outpatients department was hospitalized for the icteric form of acute hepatitis epidemica with two relapses (when he was 39 and 41 years old). Medical treatment involved corticoids. HBsAg positivity was found during subsequent hospitalization at the Department of Infectious Diseases, when he was 43 years old. Chronic persistent hepatitis was confirmed by hepatic biopsy with chronic carriage of hepatitis $B$ virus. He came to the Department of Occupational Medicine for the first time aged 49 years. Epidemiological evaluation confirmed occupational etiology. Chronic hepatitis B with positivity of HBsAg was diagnosed at the Clinic of Occupational Medicine. When he was 51 years old, he was rehospitalized for liver cirrhosis. Liver scintigraphy (99mTc colloid) detected spherical formation in left lobus, splenomegaly and increased uptake of radioactive substances. In 1985, he was readmitted to the Clinic of Infectious Diseases for decompensated liver cirrhosis and praecoma. He died at 52 of an occupational hepatocellulary carcinoma. 


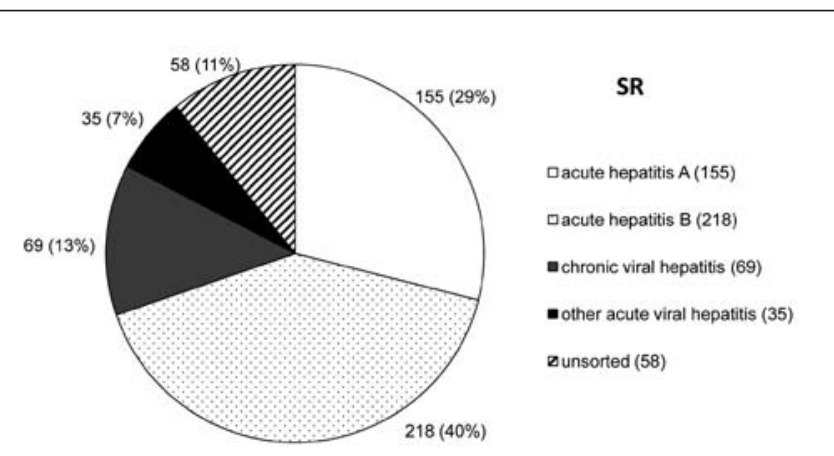

Fig. 4a Trends in the structure of occupational viral hepatitis reported in SR from 1991-2010.

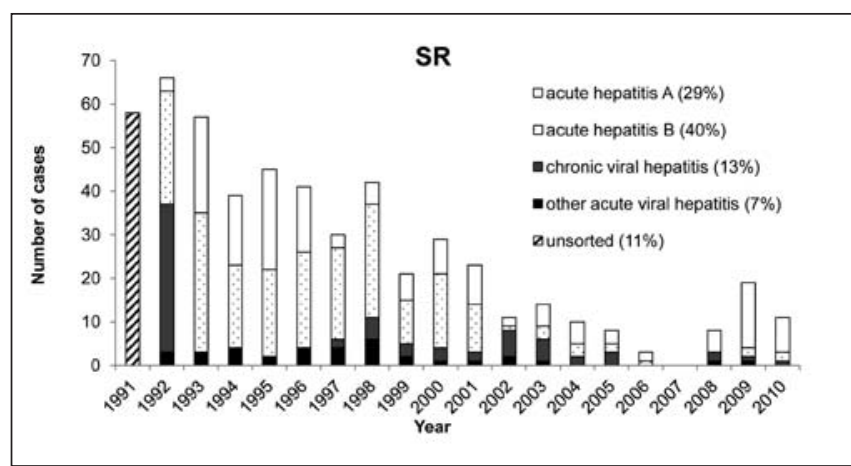

Fig. 5a Comparison of the structure of occupational viral hepatitis reported in SR from 1991-2010 according to the type of hepatitis.

\section{DISCUSSION}

Differences in the incidence rate of reported occupational infectious diseases between SR and CR were most probably caused by improved screening of infectious skin diseases during recent years in CR (occupational scabies).

Reliable diagnosis of hepatitis B have been available in the former Czechoslovakia since 1975 when routine determination of surface antigen of hepatitis B virus was introduced into practice. The incidence of hepatitis B in the general Czech population was about 25/100,000 in 1980s and 6/100,000 in the late 1990s (16).

In Slovakia, the incidence of hepatitis A and B was $26.79 / 100,000$ and $3.0 / 100,000$, respectively in 2009 , while the incidence of all forms of occupational hepatitis in healthcare workers was $17.9 / 100,000$. In 2010, only ten cases of occupational hepatitis were reported in Slovakia i.e. the incidence in healthcare workers was 0.48/100,000.

In Slovakia (Turiec Region), a decrease in the incidence rate of viral hepatitis B between years 1976-2000 was observed (17). Within the given period, the incidence rate of hepatitis B decreased in general population from $31.1 / 100,000$ to $0.9 / 100,000$ (17). The declining trend in occupational hepatitis occurrence can be attributed to the observed general trend. In Slovakia 2010, the incidence rate of VHA and VHB was 26.77 and 2.08 per 100,000 , respectively. In the same year in CR, the incidence rate of VHA was 8.2 and incidence rate of acute VHB was 2.2. per 100,000 general population. In other words, the above mentioned differences have remained resulting in differences of recorded occupational cases, as well.

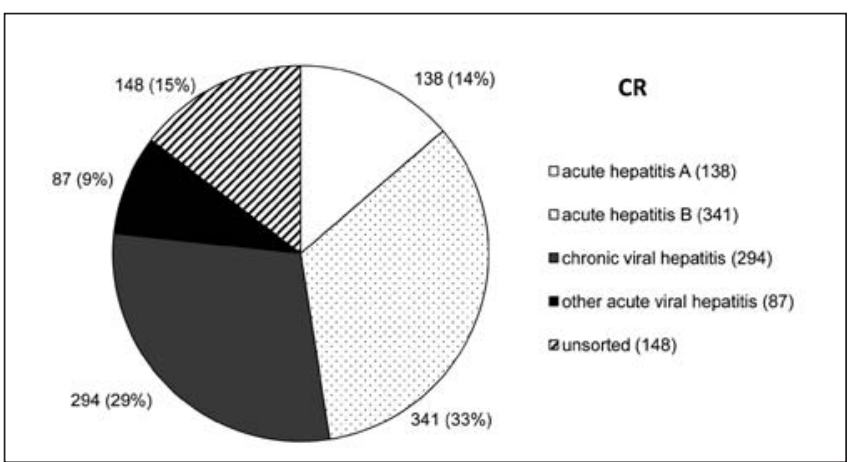

Fig. $4 b$ Trends in the structure of occupational viral hepatitis reported in CR from 1991-2010.

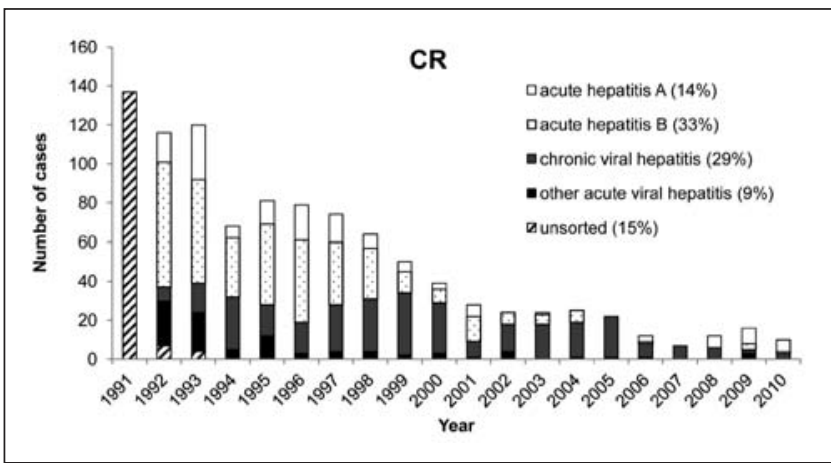

Fig. 5b Comparison of the structure of occupational viral hepatitis reported in CR from 1991-2010 according to the type of hepatitis.

Since 1976, criteria to be met for acknowledgment of hepatitis $\mathrm{B}$ as OD, have been made less strict for healthcare personnel in SR and CR. Namely, confirmation of a direct contact with an infected patient or with his biological material was no longer required. Work at high risk of exposure to infection, such as taking care after patients or manipulating with biological material, was considered as hazardous exposure and considered relevant for acknowledgement of the disease as OD. This approach was based on epidemiological evidence provided in SR by Palanová et al. (18) and by Fialová in CR (19).

Palanová et al. (18) found out in their national study that in Slovakia, 3,882 VH cases in healthcare workers were reported from 1960 to 1981 . This corresponded to the average incidence rate 287 per 100,000 healthcare personnel, which was three times higher than occurrence in general population.

Fialová (19) studied the occurrence of viral hepatitis in Moravia from 1975-1984. She also found that the incidence of $\mathrm{VH}$ in healthcare workers was higher (4.9 times) in comparison with general population living in the same territory. Specifically, the incidence of hepatitis B with HBsAg positivity was even 9.2 times higher in healthcare personnel than in general population.

In 1983, the high incidence of viral hepatitis gave impetus to the gradual implementation of obligatory vaccination against hepatitis B in healthcare workers, students at medical faculties, students at nursing schools, and in selected groups of population in $\mathrm{CR}$. This led to the dramatic decrease in hepatitis B incidence rate in healthcare workers from 177 per 100,000 healthcare workers in 1982 to 7.3 in 1999 (16). Hassmanová et al. (20) compared the occurrence of hepatitis B from 1986-1990 and from 1991-2000 
in healthcare workers in East Bohemian region. Incidence rate was 6.97 per 1,000 healthcare workers in the first period, and 3.73 per 1,000 healthcare workers in the second one. The change was attributable to the implementation of wide vaccination protection.

Vaccination against hepatitis started in Slovakia in the same time, first at hemodialysis units (18). In 1985, the Chief Medical Officer of the Slovak Republic ordered vaccination of healthcare workers in biochemistry laboratories. In 1986, he also ordered obligatory vaccination of hematologists, surgeons, orthopedics, urologists, and infectologists. In 1987, vaccination against hepatitis B at departments for internal medicine and obligatory vaccination of students at medical and nursing schools was introduced. Vaccination was later extended on other population risk groups, from 1998 to all newborns (21).

In 6-8 weeks after vaccination against hepatitis $B$, the serum level of antiHBsAg antibodies is measured; it should be higher than $10 \mathrm{U} / 1$. Significant increase in antibodies was observed mainly after revaccination with combined vaccine (VHA+VHB) (22). However, some of completely vaccinated persons do not reach protective level of antibodies but revaccination is not necessary, since the memory of immune system ensures sufficient protection. After injuries or after coincidental inoculation of an infectious material, passive immunization with hyperimmune immunoglobulin should be performed within 24 hours. In non-vaccinated persons, active immunization should be started immediately $(17,23-25)$. The success of vaccination and compliance of health care personnel with special protective measures in the workplace made it possible to change the classification of a considerable group of healthcare workers from risk category III to category II (26).

The authors focused on the epidemiological situation and approach to the prevention of occupational viral hepatitis mainly in Poland, Hungary and neighbouring countries having intense cross-border contacts with SR. Relevant data in literature on more detailed comparison between these countries is not available due to different methods in processing data at different times. However, we can point out the high risk of acquiring occupational hepatitis in health care workers and a decrease in number of hepatitis A and B cases in this population group after implementation of mandatory vaccination in these countries. Data from the available literature show such decrease in Poland and Hungary, similarly to our results from SR and CR.

In Poland, the incidence of occupational hepatitis culminated in 1987. After implementation of vaccination in 1988, the annual number of newly reported cases was gradually decreasing (27). In 2001, 291 cases of occupational hepatitis B and hepatitis C were reported (42.6\% of the total number of occupational infections) (28). In 2009, the incidence of hepatitis VHB+VHC was $0.4 / 1,000$ healthcare workers (27).

In Hungary, nine cases of occupational hepatitis were reported in 2009 (VHB, VHC, and two cases of VHE). Eight of them in non-vaccinated employees who got infected via a needlestick injury and contamination with biological material. Hepatitis represented $10.1 \%$ of all reported occupational infectious diseases (29). Incidence was $0.4 / 100,000$ insured persons. This demonstrated that the obligatory vaccination of healthcare workers against hepatitis is one of the most effective tools for reduction of the incidence of hepatitis A and B.

In the group other "hepatitis" in Fig. 4, 5, there were only a few cases registered in SR and CR. In the last decade, most of them were hepatitis $\mathrm{C}$ (VHC). However, the diagnosis was not always confirmed by the third generation enzyme immunoassay, which has sensitivity of $97 \%$ for hepatitis C $(30,31)$. In England, the prevalence of seropositivity of VHC was $2.05 \mathrm{VHC} / 100,000$ healthcare workers, which was 2.9 times higher than in blood donors (32). In Poland, the positivity for anti-VHC antibodies in healthcare workers was $1.3-3.2 \%$, whereas in the general population it was $1.5-2.0 \%$. Currently, occupational hepatitis C predominates over hepatitis B (27). In Hungarian population in 2005 , it was estimated that there were about 50,000 persons with HBsAg positivity as well as about 70,000 carriers of hepatitis C virus. Of them, only small percentage had been provided with necessary therapy (33).

Currently, we have no relevant data on VHC in general population in Slovakia. A study from the Eastern Slovakia followed 232 patients who acquired hepatitis $\mathrm{C}$ mainly through blood transfusion, surgery or parenteral drug use. The average time elapsed from the detection of increased transaminases level to the diagnosis of hepatitis $\mathrm{C}$ and to the start of therapy by infectologists was 6.3 years (34). The transmission rate of hepatitis $\mathrm{C}$ virus from a carrier after a needlestick injury is $0.4-8 \%$ (35). Up to $70-90 \%$ of infected persons become chronic carriers, irrespective of antibody positivity (31). Number of carriers can be reduced using costly treatment by peg-interpherone alpha in combination with ribavirine. Hepatitis $\mathrm{C}$ can cause liver cirrhosis in about $20 \%$ of cases, and that is associated with a high risk of hepatocellular carcinoma. Because vaccine against VHC is not available, we should focus on non-specific preventive measures, hygienic-epidemiological regime, and education, especially in young healthcare workers and auxiliary healthcare personnel.

In Europe, it is estimated that about $1 \%$ of population is infected by hepatitis $\mathrm{C}$ virus. The prevalence of HCV in Southern Europe is higher, about 2.5-3.5\% (36). Medical examination among Egyptian blood donors of various socioeconomic status revealed VHC prevalence of even 16.8\% (37). Fortunately, the VHC prevalence in SR and CR is lower. It is ranging between $0.3-0.5 \%$ (36). Mandatory detection of anti-VHC antibodies in blood donors contributes to the effective control of the spread of hepatitis $\mathrm{C}$ in SR and CR $(34,36)$.

For many years, there is a higher proportion of women working in health services in Slovakia and the Czech Republic (38). Consequently, the absolute number of occupational viral hepatitis has been significantly higher in women. On the contrary, Bilski in 2011 pointed out that the number of hepatitis in polish men or women working in health services is not significantly different (27).

\section{CONCLUSION}

During the previous two decades, the occurrence of occupational infectious diseases in general and of viral hepatitis in particular has dramatically decreased in SR, CR, and other Visegrad group countries. This happened mainly due to the introduction of mandatory vaccination against hepatitis A and B. However, we would like to emphasize that epidemiological surveillance of hepatitis should continue, especially with regard to the increased incidence of hepatitis $\mathrm{C}$.

Communicable diseases do not respect borders (39). The information gathered in our study could help set and imple- 
ment preventive measures and surveillance system of working conditions and health status of employees aimed at their health promotion and protection in order to sustain further decrease in the incidence of occupational infectious diseases, especially of viral hepatitis $(2,7,28,29,40-42)$.

\section{Acknowledgements}

This study was supported by the Research Project of Charles University $\mathrm{P} 25 / 1 \mathrm{LF} / 2$

\section{REFERENCES}

1. List of occupational diseases (revised 2010). Identification and recognition of occupational diseases: criteria for incorporating diseases in the ILO list of occupational diseases. Occupational Safety and Health Series, No. 74. Geneva: International Labour Office; 2010.

2. Vejlupková J. Selected information on the lists of occupational diseases in Europe. Prac Lek. 1994;46(1):16-21. (In Czech.)

3. Szilagyiová M, Šimeková K, et al. Infectology for practice. Bratislava: Herba; 2010. (In Slovak.)

4. Vejlupková J, Urban P. Occupational diseases in the Czech Republic in 1995. Prac Lek. 1996;48(3):103-9. (In Czech.)

5. Decree No. 128 of the Federal Ministry of Labour and Social Affairs of November 20,1975, whereby the act on social security is being executed. Sbírka zákonů ČR. 1975 Nov 24;Pt 30:707-757. (In Czech.)

6. Decree No. 149 of the Federal Ministry of Labour and Social Affairs of September 16, 1988, whereby the act on social security is being executed Sbírka zákonů ČR. 1988 Sep 22;Pt 31:861-912. (In Czech.)

7. Act No. 461 on social insurance of October 30, 2003. Zbierka zákonov SR. 2003 Oct 30;Pt 200:3550-703. (In Slovak.)

8. Pelclová D, Fenclová Z, Lebedová J. Occupational diseases in the Czech Republic in the year 1998. The need for unifying European standards/ criteria for all occupational diseases. Centr Eur J Publ Health. 2000 Feb;8(1):49-52.

9. Urban P, Cikrt M, Hejlek A, Lukáš E, Pelclová D. The Czech National Registry of Occupational Diseases. Ten years of existence. Cent Eur J Publ Health. 2000 Nov;8(4):210-2.

10. Vejlupková J, Urban P. Brief review of occupational diseases reported in the Czech Republic in 1993. Prac Lek. 1994;46(3):102-5. (In Czech.)

11. Vejlupková J, Urban P. Review of occupational diseases reported in the Czech Republic in 1994. Prac Lek. 1995;47(3):99-104. (In Czech.)

12. Fenclová $Z$, Urban $P$, Pelclová $D$, Lebedová J, Lukáš E. Occupational diseases reported in the Czech Republic in 2000. Ces Prac Lek. 2001;2(2):627. (In Czech.)

13. Fenclová Z, Urban P, Pelclová D, Lebedová J. Occupational diseases reported in the Czech republic in 2006. Ces Prac Lek. 2007;8(2):72-81. (In Czech.)

14. Fenclová Z, Havlová D, Čerstvá M, Urban P, Pelclová D, Žofka J, editors Occupational diseases in Czech Republic 2010 [Internet]. Prague: NIPH; 2011 [cited 2013 Mar 21]. Available from: http://www.szu.cz/uploads/ Hlaseni_a_odhlaseni_2010.pdf. (In Czech.)

15. Fenclová Z, Urban P, Pelclová D, Havlová D, Čerstvá M. Occupational diseases reported in the Czech Republic in 2010. Prakt Lek. 2011;91(5):263-8. (In Czech.)

16. Ćástková J, Beneš Č. Development of viral hepatitis B incidence in healthcare workers in the Czech Republic. Ces Prac Lek. 2001;2(2):75-8. (In Czech.)

17. Hudečková H, Szilágyiová M, Buchancová J, Michal L, Klimentová G. Hepatitis B as an occupational disease in medical personnel in the Turiec region from 1976-2000. Ces Prac Lek. 2002;3(3):134-6. (In Slovak.)

18. Palanová A, Masár L, Pučeková G, Magdová L, Švaningová L, Stanová V. Viral hepatitis in health care personnel in Slovakia. Cesk Epidemiol Mikrobiol Imunol. 1985;34(2):76-86. (In Slovak.)

19. Fialová J. Viral hepatitis as an occupational disease in health care workers in Olomouc, Přerov and Šumperk districts in 1975 - 1984. Prac Lek. 1988;40(3):116-21. (In Czech.)
20. Hassmanová V, Vaněčková J, Strnad L. Evaluation and development of occupational diseases in East Bohemian region in 1986-2000. Acta Medica (Hradec Králove) Suppl. 2001;44(1):35-43. (In Czech.)

21. Decree No. 585/2008 of the Ministry of Health of the Slovak Republic from December 10, 2008 on details on prevention and control of communicable diseases. Zbierka zákonov SR. 2008;Pt 202:5024-41. (In Slovak.)

22. Chlíbek R, Smetana J, Boštíková V, Špliňo M. Vaccination against viral hepatitis A and B in adults aged over 40 years-antibody persistance and immune memory. Epidemiol Mikrobiol Imunol. 2011;60(3):99-108. (In Czech.)

23. Hudečková H. Practical vaccinology not only for medical students. Žilina: Lajka; 2009. (In Slovak.).

24. Tuček M, Cikrt M, Pelclová D. Occupational medicine for practice. Prague: Grada; 2005. (In Czech.)

25. Pelclová D, Lebedová J, Lukáš E, Fenclová Z. Occupational diseases and poisoning. Prague: Karolinum; 2006. (In Czech.)

26. Suulcová M, Hubačová L, Henčeková D, Križanová D, Benkó Š. Risk works and risk factors of working environment in health services. In: Healthy workplaces. Bratislava: Univerzita Komenského; 1998. p. 54-9. (In Czech.)

27. Bilski B. Viral hepatitis as an occupational disease in Poland. Hepat Mon. $2011 \mathrm{Jul} ; 11(7): 539-43$

28. Pepłońska B, Szeszenia-Dabrowska N. Occupational diseases in Poland, 2001. Int J Occup Med Environ Health. 2002;15(4):337-45.

29. Nagy I, Nagy K, Hudák A, Brunner P, Grónai E, Kohánka V, et al. Activities of the Hungarian Occupational Health Services in 2010, the numbers of reported diseases of occupational origin and cases of increased exposure. Cent Eur J Occup Environ Med. 2010;16(3-4):127-49

30. Dény P, Zoulim F. Hepatitis B virus: from diagnosis to treatment. Pathol Biol (Paris). 2010 Aug;58(4):245-53.

31. Takahashi K, Fujimoto G. Occupational infections. In: LaDou J. Current occupational and environmental medicine. 4th ed. New York: McGrawHill Medical; 2007. p. 262-79.

32. Neal KR, Dornan J, Irving WL. Prevalence of hepatitis C antibodies among healthcare workers of two teaching hospitals. Who is at risk? BMJ. 1997 Jan 18;314(7075):179-80.

33. Gasztonyi B, Antal I, Szendy E, Pár A, Hunyady B. The legal and occupational health aspects of B and C type viral hepatitis. Orv Hetil. 2005 Dec 25;146(52):2623-8. (In Hungarian.)

34. Paraličová Z, Kristian P, Schréter I. Epidemiological survey of hepatitis $\mathrm{C}$ at the clinic of infectology and travel medicine in Košice. Epidemiol Mikrobiol Imunol. 2009;58(4):158-62. (In Slovak.)

35. Lim VK. Occupational infections. Malays J Pathol. 2009 Jun;31(1):1-9.

36. Němeček V, Strunecký O. Genotypic heterogeneity of Hepatitis C virus (HCV) from blood donors in the Czech Republic. Epidemiol Mikrobiol Imunol. 2009;58(2):63-72. (In Czech.)

37. Awadalla HI, Ragab MH, Nassar NA, Osman MA. Risk factors of hepatitis C infection among Egyptian blood donors. Cent Eur J Public Health. 2011 Dec;19(4):217-21.

38. Kneidlová M, Hrnčír E. Occupational health impairments in women reported in Czech Republic in 2001-2006. Prac Lek. 2008;60(2):68-73. (In Czech.)

39. Hnilicová H, Dobiášová K. Migrants' health and access to healthcare in the Czech Republic. Cent Eur J Public Health. 2011 Sep;19(3):134-8.

40. Wilczyńska U, Szeszenia-Dabrowska N, Sobala W, Drozdz D. Occupational diseases in Poland, 2010. Med Pr. 2011;62(4):347-57. (In Polish.)

41. Professional guidance of MoH SR about contents of preventive medical examination in relation to work. Věstník MZ SR. 2010;58 Suppl:62. (In Slovak.)

42. Decree No. 292/2008 of the Ministry of Health of the Slovak Republic from June 23, 2008 on details, range and provision of occupational health services, expert teams composition and qualifications required for specialists providing the services. Zbierka zákonov SR. 2008;Pt 112:2338-42. (In Slovak.) 